IMAGES OF RULE 
Painting possesses a truly divine power in that not only does it make the absent present (as they say of friendship), but it also represents the dead to the living many centuries later, so that they are recognized by spectators with pleasure and deep admiration for the artist. Plutarch tells us that Cassandrus, one of Alexander's commanders, trembled all over at the sight of a portrait of the deceased Alexander, in which he recognized the majesty of his king. He also tells us how Agesilaus the Lacedaemonian, realizing that he was very ugly, refused to allow his likeness to be known to posterity, and so would not be painted or modelled by anyone. Through painting, the faces of the dead go on living for a very long time. We should also consider it a very great gift to men that painting has represented the gods they worship, for painting has contributed considerably to the piety which binds us to the gods, and to filling our minds with sound religious beliefs. It is said that Phidias made a statue of Jove in Elis, whose beauty added not a little to the received religion.

Alberti On Painting, Book II. Trans. Cecil Grayson. Introduction and Notes by Martin Kemp (Penguin 1991) 


\title{
IMAGES OF RULE
}

\author{
Art and Politics in the \\ English Renaissance, 1485-1649
}

\section{David Howarth}

Senior Lecturer in Fine Art,

University of Edinburgh

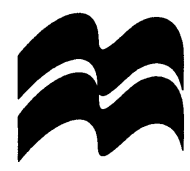


(c) David Howarth 1997

All rights reserved. No reproduction, copy or transmission of this publication may be made without written permission.

No paragraph of this publication may be reproduced, copied or transmitted save with written permission or in accordance with the provisions of the Copyright, Designs and Patents Act 1988, or under the terms of any licence permitting limited copying issued by the Copyright Licensing Agency, 90 Tottenham Court Road, London W1P 9HE.

Any person who does any unauthorised act in relation to this publication may be liable to criminal prosecution and civil claims for damages.

The author has asserted his rights to be identified as the author of this work in accordance with the Copyright, Designs and Patents Act 1988.

First published 1997 by MACMILLAN PRESS LTD

Houndmills, Basingstoke, Hampshire RG21 6XS and London Companies and representatives throughout the world

ISBN 978-0-333-51914-1 ISBN 978-1-349-25481-1 (eBook) DOI 10.1007/978-1-349-25481-1

A catalogue record for this book is available from the British Library.

This book is printed on paper suitable for recycling and made from fully managed and sustained forest sources.

$\begin{array}{llllllllll}10 & 9 & 8 & 7 & 6 & 5 & 4 & 3 & 2 & 1\end{array}$

$\begin{array}{llllllllll}06 & 05 & 04 & 03 & 02 & 01 & 00 & 99 & 98 & 97\end{array}$

Typeset by Footnote Graphics, Warminster, Wilts 
For my daughters

Jessica, Naomi and Alice 


\section{Contents}

List of Plates viii

Foreword xii

Acknowledgements $\quad$ xiv

$\begin{array}{ll}\text { Introduction } & 1\end{array}$

1 The Royal Palace 11

2 The God that Rules $\quad 50$

3 The Royal Portrait: The Tudors 77

4 The Royal Portrait: The Stuarts 120

5 The Tomb 153

6 Patrons of Power 191

7 Collecting: Patronage and Display 217

8 Writers and Critics 261

$\begin{array}{ll}\text { Appendix I } & 295\end{array}$

$\begin{array}{ll}\text { Notes } & 297\end{array}$

$\begin{array}{ll}\text { Index } & 307\end{array}$ 


\section{List of Plates}

1 St John's College, Cambridge, The Library, 1623-5 16

2 Peterhouse, Cambridge, The Chapel, 1628-32 17

3 Joris Hoefnagel, Nonsuch, 1540s engraving, 1582

4 James Basire the Elder, Somerset House, 1547-52, pen and ink with wash 20

5 Lacock Abbey, Wiltshire, 1540-49, the south side 21

6 Longleat, Horningsham, Wiltshire, c. 1580, view from the southeast

7 The Preaching Place, Whitehall, from Foxe's Actes and Monumentes, 1563

8 Francesco Villamena, Inigo Jones, 1614

9 Wenceslaus Hollar, Elevation of The Banqueting House, designed and built 1619-22

10 Plan of mainfloor and basement of Banqueting House 37

11 Simon Gribelin, 1720 engraving after Rubens, The Benefits of the Reign of James I

12 Reconstruction of Rubens' Banqueting House ceiling as originally hung; after Julius Held

13 John Webb (after Inigo Jones), Groundplan of The Star Chamber, designed 1617

14 John Webb (after Inigo Jones), Elevation of The Star Chamber

15 Bernard Baron, 1736 engraving after Hans Holbein, Henry VIII and the Barber Surgeons, 1541

16 John Webb, Whitehall Palace, sketch plans and elevation, late 1630 s onwards

17 Inigo Jones, Elevation of Old St Paul's, 1634

18 William Kent, Elevation of west front, Old St Paul's, 1727

19 Sir Anthony Van Dyck, George Gage and Companions, c. 1620-3 68

20 Sir Peter Paul Rubens, Landscape with St George and the Dragon, c. 1630

21 Sir Peter Paul Rubens, St George and the Dragon, c. 1606 
22 George Vertue engraving (1742) after Van Dyck, Charles I and Henrietta Maria, 1632

23 'The Great Picture', George Vertue c. 1737, engraving after Remigius van Leemput's copy of Holbein's Henry VIII and Family

24 Hans Holbein, Cartoon fragment for Henry VIII and Family, 1537

25 Hans Holbein, Solomon and the Queen of Sheba, c. 1535, miniature on vellum

26 'The Greate Peice', Sir Anthony Van Dyck, Charles I with Henrietta Maria, Prince Charles and Princess Mary, 1632

27 'The Rainbow Portrait', engraving after Marcus Gheeraerts (attributed), Elizabeth I, c. 1602

28 Anon., Edward VI and the Pope, c. 1570

29 Albrecht Dürer, Death of the Virgin (engraving), 151093

30 William Scrots (attributed), Edward VI, c. 1550

31 Hans Holbein, Christina of Denmark, 1538

32 Sir Peter Paul Rubens, The Presentation of the Portrait, c. $1623 \quad 98$

33 Antonis Mor, Mary I, $1554 \quad 101$

34 William Scrots (attributed), Princess Elizabeth, c. $1546 \quad 103$

35 'The Pelican Portrait', Nicholas Hilliard, Elizabeth I, c. 1575

36 Elizabeth I, Water colour of a sardonyx cameo, Anon., 18 th century

37 'The Ermine Portrait', William Segar (attributed), Elizabeth I, 1585109

38 Crispin van de Passe, Elizabeth I (engraving), late 16th century 112

39 Pieter van der Heyden, Diana and Calisto, late 16th century 113

40 Nicholas Hilliard, The Armada Jewel, c. 1588

41 Medallion portraits of Elizabeth I 117

42 Gold laurel coin (obverse), Head of James I, 1619-20 117

43 Silver medal (obverse), Head of Lady Anne Clifford, c. 1643

44 James I, Bodleian Library, Oxford, c. 1620

45 Paul Van Somer, James I, c. 1619

46 Paul Van Somer, Anne of Denmark, 1617-18 128

47 Crossbow, from Geoffrey Whitney, A Choice of Emblemes, $1586 \quad 130$

48 Robert Peake, Prince Henry and John, 2nd Lord Harington of Exton, 1603

49 Sir Anthony Van Dyck, Charles I à la chasse, 1635

50 Sir Anthony Van Dyck, Charles I on Horseback, c. 1637

51 Hubert Le Sueur, Charles I, 1629-33; originally at Roehampton; at Charing Cross since 1674

52 Sir Anthony Van Dyck, Charles I on Horseback with M. de St Antoine, 1633

53 Jacopo Tintoretto, The Flight into Egypt, 1575

54 Sir Anthony Van Dyck, Charles I in Three Positions, 1635-6 146

55 Anon., Execution of Charles I, 1649

56 William Marshall, Eikon Basilike, 1649, frontispiece 149 
57 Titian, St Catherine of Alexandria, c. 1568

58 W. Hulland after Paul Delaroche, Charles I in the Guardroom, 1836, engraving

59 Pietro Torrigiano, Tomb of Henry VII and Elizabeth of York, 1512-19, Henry VII Chapel, Westminster Abbey

60 Detail of Pietro Torrigiano, Tomb of Henry VII and Elizabeth of York, 1512-19

61 Pietro Torrigiano, High altar, Henry VII Chapel, Westminster Abbey, c. 1520-3; destroyed 1644

62 Maximilian Colt, Tomb of Elizabeth I, finished 1606, Henry VII Chapel, Westminster Abbey

63 Cornelius Cure and William Cure II, Tomb of Mary Queen of Scots, 1607-12, Henry VII Chapel, Westminster Abbey

64 Robert Herdman, Execution of Mary Queen of Scots, 1867

65 Maximilian Colt, Tomb of Princess Sophia (d. 1606), aisle, Henry VII Chapel, Westminster Abbey

66 William Hole, Hearse of Henry, Prince of Wales, 1612-13

67 Inigo Jones, Catafalque of James I, 1625, pen and brown ink with grey wash over graphite and scorelines

68 Maximilian Colt (attributed), Tomb of Sir Francis Vere, after 1609, Westminster Abbey

69 Nicholas Stone, Monument to George Villiers, 1st Duke of Buckingham, c. 1628-30, Portsmouth Cathedral

70 Francis Barlow, Pen and Ink drawing of the late 17th century, Buckingham Tomb, Henry VII Chapel, Westminster Abbey (design and marble carving by Isaac Besnier, bronze work by Hubert Le Sueur), 1630-4

71 Isaac Besnier (design and marble carving) and either Hubert Le Sueur or Francesco Fanelli (sculptors of bronze work), Tomb of Richard Weston, 1st Earl of Portland, c. 1631-35, Winchester Cathedral

72 Christopher Wren, Elevation of proposed monument to Charles I, 1679

73 Christopher Wren, Interior view of proposed monument to Charles I, 1679

74 Sir Anthony Van Dyck, Thomas Wentworth, 1st Earl of Strafford with Sir Philip Mainwaring, 1636

75 The Arms of Charles I, c. 1635, King's Manor, York

76 Sir Edward Lovett Pearce, Reconstruction of north-east elevation of Jigginstown, 1726, Naas, Co. Wicklow, Ireland

77 Sir Anthony Van Dyck, Self-portrait with Endymion Porter

78 Hans Holbein, Frontispiece to the Coverdale Bible, 1535

79 Hans Holbein, 'The Cardinal', from The Dance of Death, published 1538

80 Sir Anthony Van Dyck, Adonis and Venus (The Duke and Duchess of Buckingham), 1620-1 
81 Bernard Baron, engraving of 1740 after Van Dyck, The Pembroke Family, c. 1637

82 Sir Anthony Van Dyck, Lord George Stuart, Sieur d'Aubigny, c. 1638

83 Sir Anthony Van Dyck, The Earl of Warwick, ?1636

84 Nicholas Stone, Tomb of Dudley Carleton, Viscount Dorchester, 1640, Chapel of St Paul, Westminster Abbey

85 Hendrick de Keyser, Constantijn Huygens and Companion, 1627

86 Sir Peter Paul Rubens, Self-portrait, presented to Charles I in 1623243

87 Hans Holbein, Sir Richard Southwell, 1536

88 Anon., Silver badges for the Southwell Portrait, 1621

89 Philip Fruytiers, Arundel Family (after Van Dyck), c. 1642

256

90 Henry Lilly, Genealogie of the Princelie familie of the Howards, 1638258

91 Hans Holbein, Sir Thomas Elyot, c. 1532

92 Wenceslaus Hollar, William Prynne

93 Sir Anthony Van Dyck (attributed), Francis Junius, c. 1640

94 J. Maurer, A perspective view of Covent Garden, 1751 


\section{Foreword}

Many people have given me help with the somewhat slow and painful progress of this book. First I would like to thank Vanessa Graham, formerly of Macmillan, who gave a contract to the idea and then proceeded to show exemplary patience as various deadlines glided past. Vanessa's successor, Simon Winder, took over when matters were getting into shape. Simon has combined acuity and alertness with optimism and reassurance in balanced, equal and most welcome measures. I thought naively that once the manuscript was submitted that was that. However the ensuing months devoted to obtaining photographs and related copyright from places as far afield as Edinburgh and Boston, were made bearable by the calm efficiency of Melanie Assinder-Smith, Editorial Services Controller at Macmillan.

Amongst academic colleagues I owe a great deal to Graham Parry and Jeremy Wood, both of whom read the manuscript and who alerted me not only to errors of fact but to some larger confusions. I am, too, especially grateful to Kevin Sharpe who lent me his own microfilms of the Strafford Papers at Wentworth Woodhouse with his characteristic and expansive generosity. These served to open the door to the world of Caroline Ireland. I have to thank Olive, Countess Fitzwilliam's Wentworth Settlement Trustees and the Director, Sheffield City Libraries for permission to quote from the documents cited as the Wentworth Woodhouse Muniments in Sheffield City Libraries. Bernard Nurse, Librarian and custodian of the prints and drawings of The Society of Antiquaries of London, is someone whose instinct is to say 'yes'. As indeed he did on all occasions when, as I fear was too often the case, I made inconvenient or awkward requests for help in tracking much of the illustrative material. Without Bernard's help, the painful business of gathering illustrative material would have been even more laborious. Colin Davis and Crystal Webster of the Edinburgh University Computing Services always seemed to have time for my alarms and excursions over missing files, blank screens, dropped footnotes or the index. Their kindness made the button pressing 
business much less stressful than would have been the case otherwise. Others have patiently answered queries to do with the text, agreed to the publication of their manuscripts, or obliged by generous loan of photographs: John Adamson, David Alexander, Toby Barnard, Christopher Brown, Michael Bury, the Dowager Countess of Denbigh, Geoffrey Fisher, Susan Foister, Alastair Fowler, Derek Johns, David Hemsoll, James Holloway, Alan Hood, Peter Humfrey, Hilton Kelliher, Susanna Kerr, John Leighton, Lowell Libson, Jules Lubbock, Andrew Malkiewicz, John Newman, Tom Nicholl, Stuart Piggott, Belinda Poli, Elizabeth Powis, Joe Rock, Michael Russell, Charles Saumarez-Smith, David Starkey, Anne Thackray, Simon Thurley, Jessica White, Joanna Woodall and Christopher Wright.

I would also like to express my gratitude to The Moray Fund of The University of Edinburgh, The Marc Fitch Trust and Alex Wengraf Ltd, all of whom have provided generous funding for the illustrations.

Finally my wife Alex has been endlessly patient and supportive. She has looked after our three small daughters. It has been an experience possibly not enhanced by the presence of a distracted academic at home. 


\section{Acknowledgements}

The author and publisher wish to thank the following for permission to use copyright material.

Plates $1,2,10,13,14,17,67,69,84$, By courtesy of The Conway Library, Courtauld Institute of Art; 3, 4, 11, 15, 18, 23, 36, 41, 51, 59-63, 65, 68, 70, Reproduced by permission of The Society of Antiquaries of London; 5, 6, RCHME @ Crown Copyright; 7, 12, 39, 42, 66, 78-79, 94, Copyright British Museum; 8, 9, 22, 29, 38, 43, 64, 75, Joe Rock, Department of Fine Art, Edinburgh University; 13, 14, 67, By courtesy of The Conway Library, Courtauld Institute, and The Provost and Fellows of Worcester College, Oxford; 16, By courtesy of The Courtauld Institute Survey of Private Collections and Devonshire Collection, Chatsworth; 19, 31, 50, 85, The National Gallery, London; 20, 25, 26, 30, 34, 45, 52, 54, 86, 91, The Royal Collection (C) Her Majesty The Queen; 21, 33, 77, The Prado, Madrid; 24, 28, 58, 82, By courtesy of the National Portrait Gallery, London; 27, 47, 56, The University Library, Edinburgh; 32, 49, Réunion des Musées Nationaux, France; 35, Board of Trustees of The National Museums and Galleries on Merseyside (Walker Art Gallery, Liverpool); 37, By courtesy of The Marquess of Salisbury; 40, The Victoria and Albert Museum; 44, Thomas Photos Oxford; 46, Reproduced by permission of His Grace The Duke of Buccleuch; 48, The Metropolitan Museum of Art, Purchase, Joseph Pulitzer Bequest, 1944. (44.27); 53, Scuola Grande Arciconfraternita di S. Rocco, Venice; 55, Collection of The Earl of Rosebery - On loan to The Scottish National Portrait Gallery; 57, 1948 Fund and Otis Norcross Fund, Courtesy, Museum of Fine Arts, Boston; 71, John Crook; 72, 73, Reproduced by kind permission of The Warden and Fellows of All Souls College, Oxford; 74, Reproduced by permission of the Trustees of the Rt. Hon. Olive, Countess Fitzwilliam's Chattels Settlement, and Lady Juliet de Chair; 76, Devonshire Collection, Chatsworth, Reproduced by permission of the Chatsworth Settlement Trustees; 80, Private Collection, Courtesy of Harari and Johns, London; 81, National Galleries of Scotland; 
83, The Metropolitan Museum of Art, The Jules S. Bache Collection, 1949. (49.7.26); 87, 88, The Uffizi, Florence; 89, 90, Reproduced by permission of His Grace The Duke of Norfolk; 92, The Ashmolean Museum, Oxford; 93, The Bodleian Library, Oxford (Poole Portrait, 151). 